\title{
Treatment of low grade dysplasia in Barrett's esophagus with a new-generation cryoballoon device
}

A 53-year-old man with Barrett's esophagus (BE; C1M4), who was under regular surveillance, developed multifocal low grade dysplasia (LGD) without visible lesions ( $\mathbf{F i g} . \mathbf{1}$ a). The diagnosis of LGD was confirmed by a second expert pathologist.

As radiofrequency ablation for LGD is not reimbursed in our country, and given the previous experience with cryotherapy, we decided to treat the patient with cryoablation (C2-CryoBalloon Focal Ablation System; C2 Therapeutics, Redwood City, California, USA) ( Video 1 ).

Cryotherapy can successfully eradicate neoplastic BE by inducing extreme cold to tissue, which causes cell necrosis of the superficial esophageal layers [1]. CryoBalloon is a device that has been developed to deliver cryotherapy, with a single spray hole in the shaft covered by a compliant balloon [2,3]. The device was recently adapted to include a foot pedal control, allowing the endoscopist to self-control the axial and radial position of the diffuser head and the application of nitrous oxide. The addition of axial control avoids the need to reposition the balloon.

The cryoballoon catheter was introduced through the working channel, and the circular component of BE was treated in a 4-quadrant fashion, using the radial control, followed by axial adjustments to ablate the upper segments of BE ( $\triangleright$ Fig. 1 b). The technique was repeated until complete cryoablation of $\mathrm{BE}$ had been achieved ( $\triangleright$ Fig. $\mathbf{1}$ c). The treatment lasted for 15 minutes.

Two weeks later, the patient developed severe thoracic pain and heartburn. Endoscopy revealed grade D esophagitis and no other complications. Symptoms resolved after optimization of anti-acid therapy.

At the 3-month follow-up endoscopy, complete regeneration of $\mathrm{BE}$ to neosquamous epithelium was observed, with mild inflammation of the Z-line ( $\triangleright$ Fig.1d).

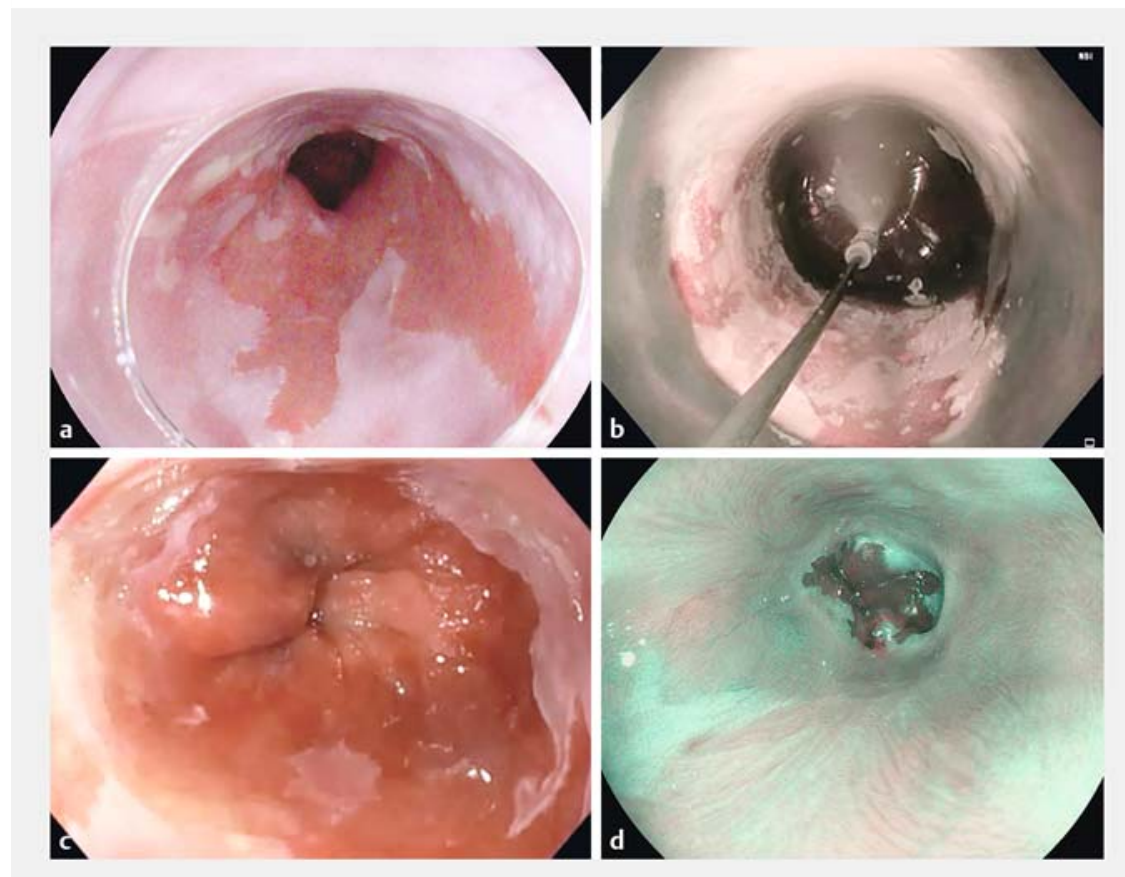

-Fig. 1 Endoscopic images. a Barrett's esophagus (C1M4) before treatment. b The cryoballoon during the application of nitrous oxide. $\mathbf{c}$ The final aspect of the esophageal mucosa immediately after cryoablation. $\mathbf{d}$ Endoscopy at 3-month follow-up, showing complete eradication of the dysplastic Barrett's esophagus after one session of cryotherapy.
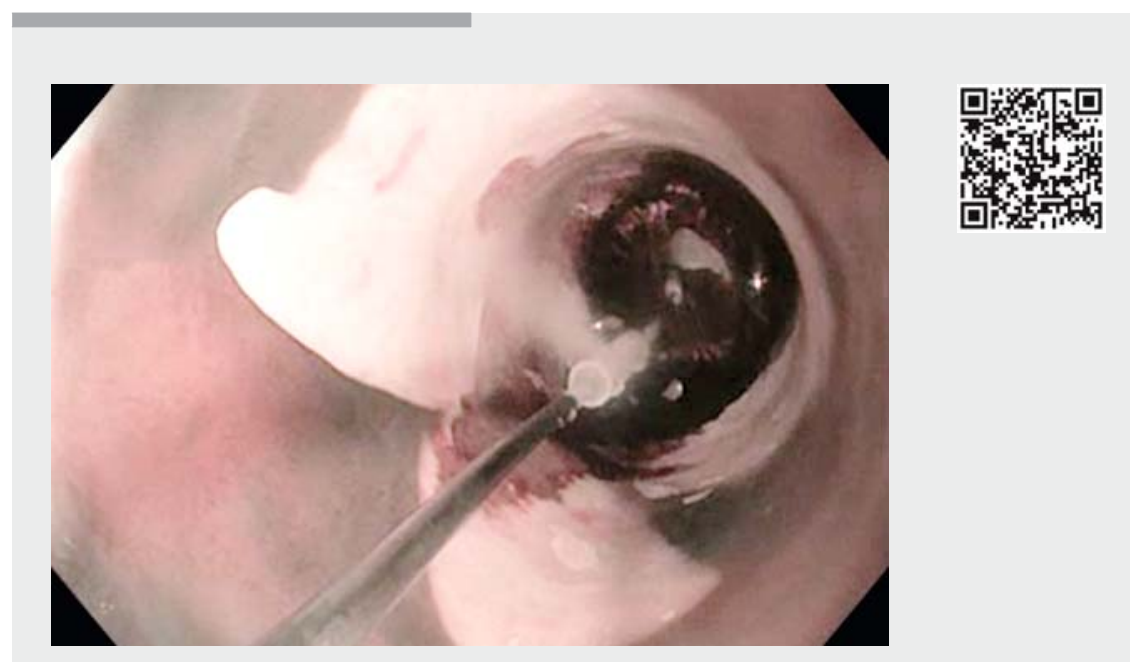

$\checkmark$ Video 1 Cryotherapy with the novel cryoballoon system to treat Barrett's esophagus with low grade dysplasia. 
Biopsies confirmed no intestinal metaplasia or dysplasia.

This case demonstrates the use of a newgeneration cryoballoon system for treatment of dysplastic BE. The treatment was effective and was facilitated by the axial movement of the diffuser, achieving full eradication of dysplastic $B E$ in a single session.

Endoscopy_UCTN_Code_TTT_1AO_2AF

\section{Competing interests}

Raf Bisschops has received consultancy fees from C2 Therapeutics.

The authors

Joana Castela, Ingrid Demedts, Raf Bisschops Department of Gastroenterology, University Hospitals Leuven, Leuven, Belgium
Corresponding author

\section{Joana Castela, MD}

Department of Gastroenterology, University Hospitals Leuven, Herestraat 49, B-3000 Leuven, Belgium Fax: +351-21-7229880

joanarocastela@gmail.com

\section{References}

[1] Gage AA, Baust ]. Mechanisms of tissue injury in cryosurgery. Cryobiology 1998; 37 : $171-186$

[2] Friedland S, Triadafilopoulos G. A novel device for ablation of abnormal esophageal mucosa (with video). Gastrointest Endosc 2011; 74: 182-188

[3] Kunzli HT, Scholvinck DW, Meijer SL et al. Efficacy of the CryoBalloon Focal Ablation System for the eradication of dysplastic Barrett's esophagus islands. Endoscopy 2017; 49: $169-175$

\section{Bibliography}

DOI https://doi.org/10.1055/a-0665-4090

Published online: 14.8.2018

Endoscopy 2018; 50: E318-E319

(c) Georg Thieme Verlag KG

Stuttgart · New York

ISSN 0013-726X

\section{ENDOSCOPY E-VIDEOS}

https://eref.thieme.de/e-videos

回回 Endoscopy E-Videos is a free access online section, reporting 回粆: on interesting cases and new

techniques in gastroenterological endoscopy. All papers include a high quality video and all contributions are freely accessible online.

This section has its own submission website at https://mc.manuscriptcentral.com/e-videos 